Comparing biomass and nutrient removals of stems and fresh and predried whole trees in thinnings in two Norway spruce experiments

Stupak, Inge; Nordfjell, Tomas; Gundersen, Per

Published in:

Canadian Journal of Forest Research

Publication date:

2008

Document version

Publisher's PDF, also known as Version of record

Citation for published version (APA):

Stupak, I., Nordfjell, T., \& Gundersen, P. (2008). Comparing biomass and nutrient removals of stems and fresh and predried whole trees in thinnings in two Norway spruce experiments. Canadian Journal of Forest Research, 38(10), 2660-2673. http://article.pubs.nrc-

cnrc.gc.ca/RPAS/rpv?hm=HInit\&calyLang=eng\&journal=cjfr\&volume=38\&afpf=x08-108.pdf 


\title{
Comparing biomass and nutrient removals of stems and fresh and predried whole trees in thinnings in two Norway spruce experiments
}

\author{
Inge Stupak, Tomas Nordfjell, and Per Gundersen
}

\begin{abstract}
In Denmark, thinning trees used for energy purposes are cut and left to dry in the stand before they are removed as whole trees. This practice causes shedding of needles and reduces nutrient removals for the benefit of long-term site fertility. It is uncertain, however, to what extent needles are shed and actual nutrient loss is affected by this practice. To address this question, we compared biomass and nutrient removals in two Norway spruce (Picea abies (L.) Karst) experiments in western Denmark. Three contemporary thinning harvest intensities were examined: harvesting of fresh whole trees, predried whole trees, and stems only. The whole trees were chipped individually, and samples were removed to determine moisture and nutrient contents, whereas sample discs were removed from harvested stems. The biomass content of the cut whole trees was estimated to decrease $17 \%$ during predrying, whereas nutrient contents decreased 35\%-60\% for N, P, and $\mathrm{K}$ and $<32 \%$ for $\mathrm{Ca}$ and $\mathrm{Mg}$. The biomass content of stems was estimated to be $35 \%-42 \%$ lower than that of fresh whole trees. The corresponding differences in nutrient contents were in the range $84 \%-89 \%$ for $\mathrm{N}$, $\mathrm{P}$, and $\mathrm{K}$ and $73 \%-80 \%$ for $\mathrm{Ca}$ and $\mathrm{Mg}$. Predrying and technological methods to reduce nutrient removals were compared and discussed.
\end{abstract}

Résumé : Au Danemark, les arbres entiers prélevés au cours des éclaircies sont coupés et séchés sur place avant d'être récoltés à des fins énergétiques. Cette pratique cause la chute des feuilles et réduit le prélèvement de nutriments au profit de la fertilité de la station à long terme. Cependant, il n'est pas certain dans quelle mesure cette pratique cause la chute des feuilles et affecte la perte réelle de nutriments. Dans cette optique, nous avons comparé le prélèvement de biomasse et de nutriments dans deux stations expérimentales d'épicéa commun situées dans l'ouest du Danemark. Nous avons étudié trois types de prélèvement couramment utilisés lors d'éclaircies : la récolte d'arbres entiers fraîchement coupés, la récolte d'arbres entiers préséchés et la récolte des troncs seulement. Pour déterminer les contenus en eau et en nutriments, les arbres entiers ont été individuellement réduits en copeaux qui ont ensuite été échantillonnés alors que des disques ont été prélevés sur les troncs récoltés. Nous avons estimé que la biomasse des arbres entiers récoltés diminuait de $17 \%$ pendant le préséchage alors que dans le cas du contenu en nutriments, ces baisses étaient de $35 \%$ à $60 \%$ pour N, $\mathrm{P}$ et $\mathrm{K}$ et de moins de $32 \%$ pour $\mathrm{Ca}$ et $\mathrm{Mg}$. Nous avons estimé que la biomasse des troncs était de 35 à $42 \%$ inférieure à celle des arbres entiers fraîchement coupés. Les différences correspondantes dans le cas du contenu en nutriments étaient de l'ordre de $84 \%$ à $89 \%$ pour $\mathrm{N}, \mathrm{P}$ et $\mathrm{K}$, et de $73 \%$ à $80 \%$ pour $\mathrm{Ca}$ et $\mathrm{Mg}$. Le préséchage et les méthodes technologiques pour réduire le prélèvement des nutriments ont été comparés et abordés dans la discussion.

[Traduit par la Rédaction]

\section{Introduction}

Substitution of fossil fuel with biofuel, including wood chips produced from forest biomass residues, is projected to increase in the coming decades as a contribution to the commitment in the Kyoto Protocol and the development of a sustainable and domestic energy supply system in Europe (European Commission 1997). However, the removal of forest biomass residues increases the export of nutrients from the forest and, at variance with the principles of sustainable forest management, potentially speeds up the degradation of production potential (Raulund-Rasmussen et al. 2008). Tradi- tional firewood and whole-tree chips from first, second, and sometimes third thinnings are the most common primary forest biomass sources used in Danish energy production. In other countries there is also a large interest in the potential of precommercial thinnings. The utilization of whole-tree chips from thinnings is now so extensive in Denmark that the potential for increased use from this source is insignificant (Nord-Larsen and Heding 2003). In 2003 and 2004, the total harvested volume from forests in Denmark was 1.8-1.9 $\times 10^{6}$ solid $\mathrm{m}^{3}$, and of these about $20 \%$ was harvested as wood chips (Statistics Denmark 2007). The upper diameter at breast height limit for whole-tree harvesting is presently $12-16 \mathrm{~cm}$

Received 26 November 2007. Accepted 5 July 2008. Published on the NRC Research Press Web site at cjfr.nrc.ca on 25 September 2008.

I. Stupak ${ }^{1}$ and P. Gundersen. Forest \& Landscape Denmark, University of Copenhagen, Hørsholm Kongevej 11, DK-2970 Hørsholm, Denmark.

T. Nordfjell. Department of Forest Resource Management, Section of Planning and Operational Efficiency, Swedish University of Agricultural Sciences, Skogsmarksgränd, 90183 Umeå, Sweden.

${ }^{1}$ Corresponding author (e-mail: ism@life.ku.dk). 
(Nord-Larsen and Heding 2003), but occasionally trees with stems as large as timber size, about $30 \mathrm{~cm}$ in diameter, are chipped.

As a mitigation measure against increased nutrient removals in whole-tree harvesting, the Danish Forest and Nature Agency recommends that trees are cut and left to dry in the stand for one summer season (Billeschou and Klitgaard 1985). Transpiration after cutting causes shedding of nutrient-rich needles, with associated reductions in nutrient removals being relatively large compared with the reduction in biomass yields. Various techniques have also been suggested for leaving some portion of fresh biomass directly in connection with cutting and harvesting (Koistinen and Äijälä 2005).

This study addresses questions about the efficiency of predrying as a measure for retaining the nutrients in the stand and about how nutrient removals can be estimated in general. Estimates of nutrient removals can be obtained by combining biomass equations (e.g., Marklund 1988; Wirth et al. 2004; Zianis et al. 2005) with information on nutrient concentrations in biomass (e.g., Kimmins et al. 1985) or by directly applying nutrient equations to individual trees (e.g., Andersson et al. 1998) or stands (e.g., Augusto et al. 2000). For Denmark, such knowledge is scarce, usually site specific, or addresses only a single tree component (e.g., Ingerslev and Hallbäcken 1999; Bergstedt and Olesen 2000; Skovsgaard et al. 2006).

Estimates of biomass and nutrient removals after predrying may be based on the assumption that all needles are lost during predrying. Norway spruce (Picea abies (L.) Karst) needles are shed relatively easily (Simola and Mäkelä 1976). Despite this, needle shedding is not necessarily complete (Møller 2000). The removed trees may furthermore be contaminated with topsoil that adds to the amount of biomass and nutrients removed. On the other hand, twigs, branches, and other tree material may also be lost during felling, handling, and chipping in the stand. Based on field observations, biomass removals after predrying have been quantified for logging residues on clearcuts (e.g., Thörnqvist 1984; Flinkman et al. 1986; Lehtikangas and Jirjis 1993) but only rarely for whole trees harvested in thinnings.

The aim of this study was to qualify general discussions on how to obtain acceptable harvesting intensities and on predrying as a method to reduce nutrient removals in whole-tree harvesting specifically. This was addressed by performing field experiments that allowed quantification of differences in harvesting intensity. Biomass and nutrient removals were compared for three contemporary harvesting intensities in thinnings of Norway spruce: harvesting of fresh whole trees, harvesting of predried whole trees, and harvesting of stems only. Two experimental stands in Denmark were used for the purpose. The effects of tree size, site, and stand conditions were analysed and discussed to determine whether biomass and nutrient removals after predrying can be modelled using existing knowledge and assuming complete needle shedding.

\section{Materials and methods}

\section{Site description and experimental design}

Sampling took place in two existing experiments designed to study the effect of whole-tree harvesting on stem volume increment. The experiments were established in 1989-1990 in two even-aged Norway spruce stands at Klosterheden National Forest (klh) and Mangehøje Forest (mgh) (NordLarsen 2001; Nord-Larsen 2002). Site and stand characteristics are presented in Table 1. The stand at mgh consisted of about 95\% Norway spruce and 5\% silver fir (Abies alba Miller), with some silver firs still being present at the time of sampling. Both sites were situated in the western part of Jutland, Denmark, with a distance of about $10 \mathrm{~km}$ between them.

The experiment on each site had a randomized block design with four treatments (harvesting intensities) and four blocks, with one replicate per block. Each plot was approximately 0.1 ha and surrounded by a $4 \mathrm{~m}$ wide buffer strip. Only three of the treatments were used in this study: wholetree harvesting in which the felled trees were removed immediately after thinning (fresh whole-tree harvesting, fwth); whole-tree harvesting in which the felled trees were left to dry in the stand for one growing season before they were removed (dry whole-tree harvesting, dwth), and harvesting of stems only (stem). For the purpose of this study, it was decided to include tops, that is, the total stem, in stem harvesting, as top diameter is changed deliberately depending on market conditions (see Table A1 for nomenclature).

\section{Sampling}

Measurements and sampling were performed in connection with the second thinning, which took place on 14-15 June 2000. The thinning trees were selected to ensure an even distribution of the remaining trees, with preference given to smaller trees and also to larger trees of low quality. Before felling, five sample trees were selected among the thinning trees in each fwth and dwth plot. Three sample trees were selected in each stem plot. All sample trees were chosen to represent the diameter range of the plots (minimum-maximum). The diameter range was divided into five intervals of equal length and a sample tree was selected randomly within each interval with a minimum distance of $5 \mathrm{~m}$ between them. In the fwth and dwth plots, all thinning trees were cut with a feller buncher and left in the strip roads in windrows, which were initially approximately $2-3 \mathrm{~m}$ wide and $1-1.5 \mathrm{~m}$ high. In the stem plots, all thinning trees were cut and delimbed with a harvester.

Diameter at breast height $(1.3 \mathrm{~m})$, total tree height from the ground, and crown height were measured for felled sample trees in the fwth plots prior to chipping of the individual trees. Crown height was defined as distance from the ground to the crown limit, which was further defined as the lowest whorl with at least two living branches. The chips of the individual trees were collected in the $16 \mathrm{~m}^{3}$ large container of the chip harvester and tipped onto a $4 \mathrm{~m} \times 6 \mathrm{~m}$ tarpaulin on the ground. The chips from each tree were shovelled into boxes and weighed. One wood chip sample was removed per tree for determination of moisture content. The distribution of coarse and fine material in the chip pile was attempted to be reproduced by turning each cardboard box upside down over a plastic box containing six cups. One cup per cardboard box, for large trees every second cardboard box, was removed and pooled, resulting in one sample 
Table 1. Site and stand information. ${ }^{a}$

\begin{tabular}{|c|c|c|c|}
\hline Site & Unit & Klosterheden (klh) & Mangehøje (mgh) \\
\hline $\begin{array}{l}\text { Geographical coordinates, European } \\
\text { datum } 1950\end{array}$ & $\mathrm{~m}$ & Zone 32, E464790, N6260320 & Zone 32, E470270, N6251410 \\
\hline Annual precipitation & $\mathrm{mm}$ & 813 & 842 \\
\hline Mean annual temperature & ${ }^{\circ} \mathrm{C}$ & 7.8 & 7.5 \\
\hline Elevation above sea level & $\mathrm{m}$ & 33 & 48 \\
\hline Distance to North Sea & $\mathrm{km}$ & 18 & 25 \\
\hline Parent material & - & $\begin{array}{l}\text { Well drained, coarse fluvial sand from the } \\
\text { Weichsel glaciation }\end{array}$ & Coarse, diluvial sand from the Saale glaciation \\
\hline \multicolumn{4}{|l|}{ Texture, Ae and B horizons } \\
\hline Coarse sand & $\%$ & 55 & 77 \\
\hline Fine sand & $\%$ & 30 & 14 \\
\hline Silt & $\%$ & 8 & 3 \\
\hline Clay & $\%$ & 4 & 2 \\
\hline Humus & $\%$ & 3 & 3 \\
\hline \multicolumn{4}{|l|}{$\mathrm{pH}$ in soil $\left(0.01 \mathrm{~mol} \cdot \mathrm{L}^{-1} \mathrm{CaCl}_{2}\right)$} \\
\hline Organic layer & - & 2.9 & 2.9 \\
\hline Top mineral soil & - & 4.0 & 3.9 \\
\hline Site index, $\mathrm{H}_{100}^{b}$ & $\mathrm{~m}$ & 24 & 27 \\
\hline Danish site index (West-Nielsen 1950) & & 5 & 4 \\
\hline Stand age from seed & years & 48 & 39 \\
\hline Earlier thinnings ${ }^{c}$ & & 1990, row thinning + selective thinning & 1990, nursing crop removed + selective thinning \\
\hline Mean square diameter & $\mathrm{cm}$ & 13 & 12 \\
\hline $\begin{array}{l}\text { Height corresponding to mean square } \\
\text { diameter }\left(H_{\mathrm{g}}\right)\end{array}$ & $\mathrm{m}$ & 11 & 9 \\
\hline Stem density $(N)$ & no. $\cdot$ ha $^{-1}$ & 2400 & 2500 \\
\hline Basal area & $\mathrm{m}^{2} \cdot \mathrm{ha}^{-1}$ & 29 & 26 \\
\hline Stem volume & $\mathrm{m}^{3} \cdot \mathrm{ha}^{-1}$ & 180 & 145 \\
\hline Relative spacing index ${ }^{d}$ & & 0.18 & 0.22 \\
\hline
\end{tabular}

${ }^{a}$ Nord-Larsen (2001) and Nord-Larsen (2002). Stand data were measured just before thinning and sampling in 2000.

${ }^{b}$ Height of the mean basal area tree at stand age 100 .

${ }^{c}$ No information available on the thinning regime. The amounts of biomass and nutrients removed in 1990 are given by Nord-Larsen (2002).

${ }^{d}$ Defined as $(10000 / N)^{0.5} / H_{\mathrm{g}}$.

per tree. The sample fresh mass measured immediately after sampling was $2-3 \mathrm{~kg}$.

In the dwth plots, whole trees were left to dry on the strip roads until 19-20 February 2001. The visual impression was that a large number of the needles had been shed, but that both green and brown needles still remained attached to the branches of the predried trees just before chipping. Measurements and sampling were performed as for fwth, except that crown height was not measured.

In the stem plots, diameter at breast height and tree height of sample trees were measured, and the total stem was weighed after cutting into manageable pieces. Two stem discs were removed from the middle of the upper and lower parts of the commercial stem and pooled into one sample. Additionally, one sample disc was removed from the middle of the noncommercial top. The top diameter was $5 \mathrm{~cm}$. The bark was soft, owing to the late fellings, whereby a large part of it was unintentionally striped off by the harvester before weighing of stems and sampling of the stem discs. Consequently, stem nutrient concentrations and removals were expected to be lower in this study compared with stems from typical thinnings performed outside the growing season. No additional sampling was performed to quantify the percentage of bark stripped off and the consequences for stem nutrient removals.

In total, 90 trees were sampled. Fourteen trees were missing compared with the experimental layout (104 trees), owing to the time constraints of the entrepreneurs.
Biomass removals were also measured at stand level in the fwth and dwth plots by collecting the harvested chips from the individual plots in separate containers and weighing them at the heating plant. Wood chip samples were removed from the containers for determination of moisture contents and nutrient concentrations. The results of these stand level measurements of biomass and nutrient removals are shown in Table 2 with soil pools as background information for the results obtained from individual tree measurements.

\section{Chemical analyses}

The samples were dried at approximately $55^{\circ} \mathrm{C}$ until constant mass for determination of moisture contents. The mean moisture content for wood chip or stem disc samples from the three harvesting intensities, fwth, dwth, and stem, were $48 \%, 47 \%$, and $41 \%$ at $\mathrm{klh}$ and $53 \%, 46 \%$, and $48 \%$ at mgh, respectively. SD was $2 \%-5 \%$.

The dried samples from each tree were ground in a Retsch SM2000 mill with a $10 \mathrm{~mm}$ riddle and thereafter distributed evenly on a paper sheet. One of four equally divided quarters was randomly selected. This procedure continued until a subsample of about $5 \mathrm{~g}$ had been obtained. The subsample was ground in a Tecater sample mill with a $0.5 \mathrm{~mm}$ mesh sieve. The sample was mixed, and a subsample of about $150 \mathrm{mg}$ was removed afterwards. The subsample was digested in concentrated nitric acid in a PTFE bomb in a microwave oven, and concentrations of $\mathrm{P}, \mathrm{K}, \mathrm{Ca}$, and 
Table 2. Soil pools ${ }^{a}$ and mean dry mass and nutrient removals at stand level for the two experimental sites $^{b}$ (Forest \& Landscape Denmark, unpublished data, 2000-2001).

\begin{tabular}{|c|c|c|c|c|c|c|c|}
\hline \multirow[b]{2}{*}{ Site } & \multirow{2}{*}{$\begin{array}{l}\text { Harvesting } \\
\text { intensity or } \\
\text { soil horizon }\end{array}$} & \multirow[b]{2}{*}{ Biomass (tonnes $\cdot \mathrm{ha}^{-1}$ ) } & \multicolumn{5}{|c|}{ Nutrient removals $\left(\mathrm{kg} \cdot \mathrm{ha}^{-1}\right)$} \\
\hline & & & $\mathrm{N}$ & $\mathrm{P}$ & $\mathrm{K}$ & $\mathrm{Ca}$ & $\mathrm{Mg}$ \\
\hline \multicolumn{8}{|c|}{ Biomass and nutrient removals } \\
\hline \multirow[t]{2}{*}{ klh } & fwth & $30(8)$ & 88 (19) & $10(2)$ & $40(10)$ & 77 (19) & $14(3)$ \\
\hline & dwth & $25(4)$ & $56(16)$ & $4(1)$ & $20(7)$ & $50(15)$ & $11(4)$ \\
\hline \multirow[t]{2}{*}{ mgh } & fwth & $19(3)$ & $54(18)$ & $5(2)$ & $25(9)$ & $41(6)$ & $11(3)$ \\
\hline & dwth & $20(3)$ & $51(18)$ & $4(2)$ & $19(9)$ & $46(6)$ & $10(3)$ \\
\hline \multicolumn{8}{|c|}{ Soil nutrient pools } \\
\hline \multirow[t]{2}{*}{ klh } & O horizon & & 1010 & 1 & 15 & 137 & 12 \\
\hline & Mineral soil & & 7677 & 10 & 153 & 418 & 128 \\
\hline \multirow[t]{2}{*}{ mgh } & O horizon & & 1128 & 2 & 14 & 167 & 9 \\
\hline & Mineral soil & & 6477 & 23 & 91 & 452 & 89 \\
\hline
\end{tabular}

Note: See Table A1 for nomenclature. Values in parentheses are the SDs among the four plots. klh, Klosterheden National Forest; mgh, Mangehøje Forest; fwth, fresh whole-tree harvesting; dwth, dry whole-tree harvesting.

${ }^{a}$ Total pools of $\mathrm{N}$ and extractable pools of $\mathrm{P}, \mathrm{K}, \mathrm{Ca}$, and $\mathrm{Mg}$ to a mineral soil depth of $75 \mathrm{~cm}$ (Nord-Larsen 2002).

${ }^{b}$ Dry mass and nutrient removals in the former thinning have been published by Nord-Larsen (2002).

$\mathrm{Mg}$ were measured by ICP-OES, Perkin Elmer, Optima 3000 XL. N concentration was determined from a subsample of about $200 \mathrm{mg}$ using a LECO NS-2000 Analyzer (Dumas method). A reference material developed from the material analysed in Møller (2000) was used to calibrate the analyses. The materials were processed and analysed in two separate runs: fwth and stem during autumn 2000 and dwth during spring 2001.

\section{Statistical analysis and calculation}

In our analyses, the dependent variables were total dry mass and nutrient contents of the individual trees $\left(Y_{Z}\right.$, where $Z$ is $\mathrm{N}, \mathrm{P}, \mathrm{K}, \mathrm{Ca}$, or $\mathrm{Mg}$ ). $Y_{Z}$ values were obtained by multiplying the nutrient concentrations of the individual wood chip sample $\left(c_{Z}\right)$ by the amount of dry mass of the individual trees ( $Y_{\mathrm{DW}}$, where DW is dry mass). Nutrient contents of stems were obtained by multiplying nutrient concentrations of the pooled sample by the dry mass of the commercial stem part, multiplying nutrient concentrations of the top sample by the dry mass of the top, and then adding these together. An overview of the nomenclature is given in Table A1.

The data exhibited heteroscedasticity, which is almost always the case for this type of data. Double logarithmic transformation is often used to stabilize the variance (Wirth et al. 2004; Zianis et al. 2005), even if additional transformations have been applied (Marklund 1988). In this case logarithmic transformations stabilized the variance. When logarithmic transformation is used, predicted values should be corrected to compensate for logarithmic bias when converted back to arithmetical scales. The correction factor $(\mathrm{CF})$ is

$$
\mathrm{CF}=\frac{\Sigma \mathrm{MS}}{2}
$$

where $\Sigma$ MS is the sum of squared SDs of the random effects and the residuals (Flewelling and Pienaar 1981).

Diameter at breast height is a powerful predictor of tree biomass (e.g., Marklund 1988; Wirth et al. 2004; Zianis et al. 2005). This is a logical consequence of the allometric relationships within the tree; for example, the stem is approximately cone-shaped. Tree height, crown height or length, age, site index, and other variables may also add significantly to the amount of explained variance. In this study, the effect of age and site index was confounded with that of site, and crown height was only measured in fwth. The final tested predictors were

- diameter at breast height, $d(\mathrm{~cm})$

- total tree height, $h(\mathrm{~m})$

- crown height, ch (m)

- harvesting intensity, HI (fwth, dwth, and stem)

- site, $S$ (klh and mgh)

- block, $B$ (four blocks at each site)

- plot, PL (one plot per site and harvesting intensity)

Block was nested within site, and plot was nested within block and site $(\mathrm{PL}=B \times \mathrm{HI})$. The following analyses and calculations were performed:

A. Testing the fixed effects of diameter, height, harvesting intensities, and site and the random effects of block and plot on individual tree dry mass and nutrient contents. Parameters of the final model were estimated.

B. Testing fixed effects of diameter, height, and harvesting intensities and the random effects of site, block, and plot on individual tree dry mass and nutrient contents. Parameters of the final model were estimated, including correction for logarithmic bias.

C. Testing models in which predictors were included successively to explore their importance as expressed by increase in $R^{2}$.

D. Quantifying the relative differences between different harvesting intensities and sites based on parameter estimates from $\mathrm{A}$ and $\mathrm{B}$.

E. Establishing equations for height and crown height.

Analyses A, B, and C formed the basis for discussing the influence of tree size, site, and stand conditions on biomass 
Table 3. Ranges (minimum-maximum) of the measured variables.

\begin{tabular}{|c|c|c|c|c|c|c|}
\hline \multirow[b]{2}{*}{ Variable } & \multicolumn{3}{|c|}{ Klosterheden (klh) } & \multicolumn{3}{|c|}{ Mangehøje (mgh) } \\
\hline & fwth & dwth & stem & fwth & dwth & stem \\
\hline$n$ & 20 & 19 & 7 & 19 & 16 & 9 \\
\hline$d(\mathrm{~cm})$ & $6.0-21.8$ & $7.0-19.9$ & $7.9-19$ & $5.7-19.2$ & $6.5-18.5$ & $8.7-16.9$ \\
\hline$h(\mathrm{~m})$ & $6.3-14.5$ & $6.7-14.1$ & $8.2-13.1$ & $5.5-11.3$ & $6.6-11.4$ & $7.5-11.4$ \\
\hline $\operatorname{ch}(\mathrm{m})$ & $2.8-6.8$ & - & - & $3.2-6.3$ & - & - \\
\hline \multicolumn{7}{|c|}{ Nutrient concentrations $(c)$} \\
\hline $\mathrm{N}\left(\mathrm{mg} \cdot \mathrm{g}^{-1}\right)$ & $1.6-3.9$ & $1.4-2.8$ & $0.5-0.9$ & $2.2-4.8$ & $1.9-3.6$ & $0.5-0.8$ \\
\hline $\mathrm{P}\left(\mathrm{mg} \cdot \mathrm{g}^{-1}\right)$ & $0.13-0.57$ & $0.09-0.28$ & $0.04-0.09$ & $0.11-0.38$ & $0.12-0.29$ & $0.03-0.06$ \\
\hline $\mathrm{K}\left(\mathrm{mg} \cdot \mathrm{g}^{-1}\right)$ & $0.8-2.0$ & $0.3-1.1$ & $0.2-0.5$ & $0.8-1.8$ & $0.4-1.1$ & $0.2-0.5$ \\
\hline $\mathrm{Ca}\left(\mathrm{mg}^{\circ} \mathrm{g}^{-1}\right)$ & $1.9-4.3$ & $1.9-3.2$ & $0.7-1.4$ & $1.3-3.3$ & $1.5-3.2$ & $0.7-1.1$ \\
\hline $\mathrm{Mg}\left(\mathrm{mg} \cdot \mathrm{g}^{-1}\right)$ & $0.38-0.71$ & $0.27-0.48$ & $0.16-0.24$ & $0.41-0.81$ & $0.34-0.68$ & $0.18-0.28$ \\
\hline \multicolumn{7}{|c|}{ Individual tree contents $(Y)$} \\
\hline $\mathrm{DW}\left(\mathrm{kg} \cdot \operatorname{tree}^{-1}\right)$ & $8-166$ & $9-112$ & $11-81$ & $8-114$ & $8-83$ & $10-50$ \\
\hline $\mathrm{N}\left(\mathrm{g} \cdot \operatorname{tree}^{-1}\right)$ & $12-500$ & $13-289$ & $9-45$ & $27-465$ & $20-216$ & $7-31$ \\
\hline$P\left(g \cdot\right.$ tree $\left.^{-1}\right)$ & $1-57$ & $1-27$ & $1-5$ & $2-22$ & $1-17$ & $1-2$ \\
\hline $\mathrm{K}\left(\mathrm{g} \cdot \operatorname{tree}^{-1}\right)$ & $6-233$ & $2-88$ & $4-36$ & $11-162$ & $6-94$ & $3-21$ \\
\hline $\mathrm{Ca}\left(\mathrm{g} \cdot \operatorname{tree}^{-1}\right)$ & $27-438$ & $18-354$ & $16-85$ & $17-184$ & $20-224$ & $9-38$ \\
\hline $\operatorname{Mg}\left(\mathrm{g} \cdot \operatorname{tree}^{-1}\right)$ & $3-86$ & $3-52$ & $2-13$ & $4-61$ & $4-45$ & $2-10$ \\
\hline
\end{tabular}

Note: See Table A1 for nomenclature.

and nutrient removals. The parameters of the final models from analyses A and B were used to quantify the relative differences in individual tree biomass and nutrient contents among harvesting intensities and between the two sites (analysis D). Analysis E provided a description of the stands in addition to Table 1. The tests were performed using the SAS version 9.1 (SAS Institute Inc. 2002-2003) using PROC MIXED with a lower boundary constraint of zero for covariance estimates (analyses A, B, and E), or PROC GLM (analysis C). The significance level was set to 0.05 . Residuals were checked by graphical inspection of plots and by performing standard tests for zero mean and normality in PROC UNIVARIATE. The details of the analyses are described in Appendix A.

\section{Results}

\section{Basic measurements}

The measured variables varied greatly (Table 3 ). Diameters were in the range of 6-22 cm, heights in the range of 6-15 $\mathrm{m}$, individual tree dry masses in the range of 8 $166 \mathrm{~kg}$, and nutrient concentrations in the range of, for example, $\mathrm{N}$ from $0.5-4.8 \mathrm{mg} \cdot \mathrm{g}^{-1}$. Diameters, heights, and crown heights were approximately at the same level for the two sites, with the slope of the diameter-height relationship being slightly steeper for klh compared with mgh (Fig. 1), whereas crown heights were not significantly different.

\section{Influence of tested predictors}

When site was included as a fixed effect, the main effect of diameter was significant and there was a significant interaction between site and height and site and harvesting intensity (Table B1; Fig. 2). The covariance of block and plot constituted $5 \%-30 \%$ of the residual variance. The random effects were not significant, but were nevertheless left in the model. Crown height was only measured for fwth plots, but for these plots the effect on individual nutrient contents
Fig. 1. Differences in height and crown height relationships with diameter for the two sites. Height equations: $h=-4.73+6.08 \ln d$ (Klosterheden National Forest; klh), $h=-2.53+4.791 n d$ (Mangehøje Forest; mgh); crown height equations: $c h=-0.42-$

$3.12 \ln d+5.77 \ln h(\mathrm{klh}), \mathrm{ch}=-0.51-3.12 \ln d+5.77 \ln h(\mathrm{mgh})$. See Table A1 for nomenclature and units.

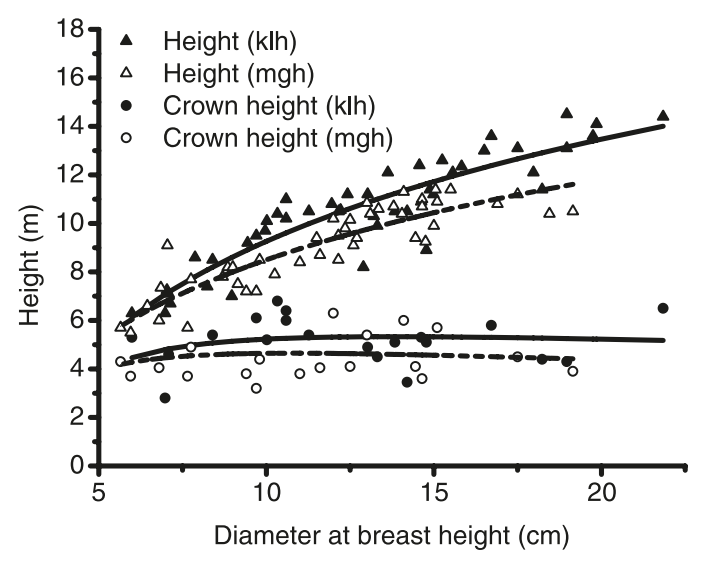

was significant, except for $\mathrm{P}$ and $\mathrm{K}$. The parameter estimates for crown height were negative, meaning that biomass or nutrient contents were larger for small crown heights and vice versa; that is, trees with taller crowns contained more biomass and nutrients.

When site was included as a random variable, the main effects of diameter, height, and harvesting intensity were significant, whereas no interaction among them were significant (Table B2). For dry mass, the covariance of site constituted $4 \%$ of the residual variance, for $\mathrm{P}$ and $\mathrm{K}, 0 \%$, and for $\mathrm{N}, \mathrm{Ca}$, and $\mathrm{Mg}, 22 \%-41 \%$. The block covariance constituted $2 \%-24 \%$ of the residual variance. The random effects were not significant, but were nevertheless left in the model. The significance of crown height effects in fwth plots weakened when site was included as a random variable. It was how- 
Fig. 2. Dry mass and nutrient contents of individual trees for the different harvesting intensities and sites. The legend is for measured data, and lines are for modelled data (Table B1), with solid lines for klh and broken lines for mgh. Input heights were calculated from diameterheight regressions (Fig. 1). fwth, fresh whole-tree harvesting; dwth, dry whole-tree harvesting; stem, harvesting of stems only.
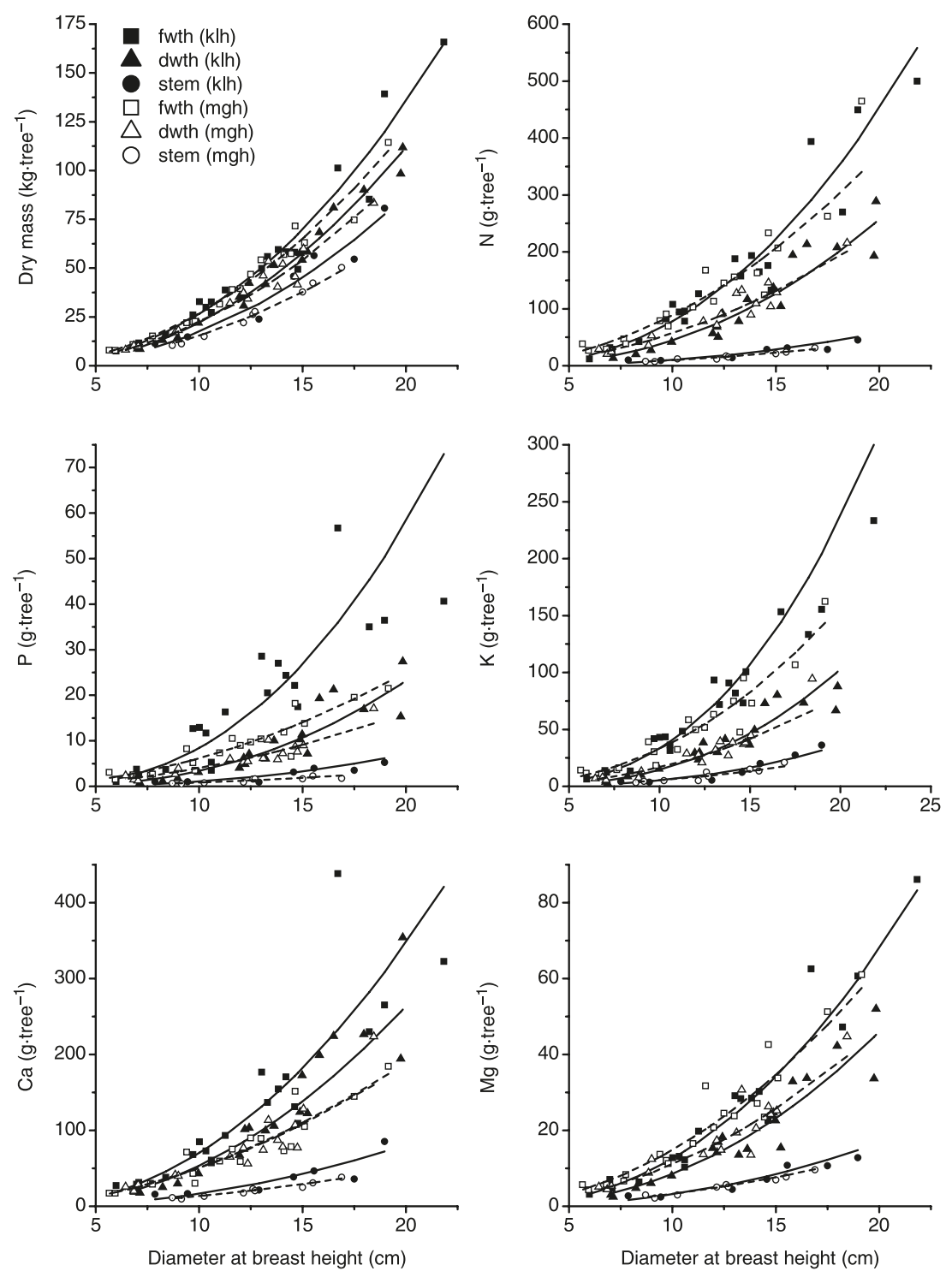

Table 4. $R^{2}$ values for successive models when including one factor successively in PROC GLM: (1) $\ln d$, (2) $\ln d$ and HI, (3) $\ln d$, HI, and $\ln h$, etc. (from models $A 8-A 9$ ).

\begin{tabular}{llllllll}
\hline & & $\mathrm{DW}$ & $\mathrm{N}$ & $\mathrm{P}$ & $\mathrm{K}$ & $\mathrm{Ca}$ & $\mathrm{Mg}$ \\
\hline$(1)$ & $\ln d$ & 0.922 & 0.413 & 0.428 & 0.525 & 0.558 & 0.588 \\
$(2)$ & $\mathrm{HI}$ & 0.978 & 0.949 & 0.881 & 0.936 & 0.908 & 0.938 \\
$(3)$ & $\ln h$ & 0.986 & 0.952 & 0.897 & 0.939 & 0.924 & 0.938 \\
$(4)$ & $S$ & 0.986 & 0.956 & 0.899 & 0.939 & 0.934 & 0.947 \\
$(5)$ & $S \times \ln h$ & 0.988 & 0.963 & 0.910 & 0.947 & 0.939 & 0.951 \\
$(6)$ & $\mathrm{HI} \times S$ & 0.988 & 0.965 & 0.921 & 0.949 & 0.944 & 0.954 \\
\hline
\end{tabular}

Note: See Table A1 for nomenclature.

ever still significant for $\mathrm{Mg}$ and almost significant for $\mathrm{N}$ and $\mathrm{Ca}(p \approx 0.06)$.

The largest part of the observed variance in dry mass, $92 \%$, could be explained by diameter alone (Table 4). When harvesting intensity was added to the model, $98 \%$ of

the variance could be explained. For nutrients, diameter alone explained $41 \%-59 \%$ of the variance, and including harvesting intensity increased the explained amount of variance to $88 \%-95 \%$. Including site, height, and significant interactions explained a further $1 \%-4 \%$ of the variance. When the fwth plots were analysed alone, the effect of crown height was significant, but it added $<1 \%$ to the amount of explained variance when site, diameter, height, and the interaction between site and height were already included.

\section{Differences in biomass and nutrient removals}

The dry mass of predried whole trees was estimated to be $17 \%$ lower compared with that of fresh whole trees on both sites (Table 5). The 95\% confidence intervals around the estimates ranged from $13 \%$ to $22 \%$. The corresponding decreases in nutrient removals were largest for $\mathrm{N}, \mathrm{P}$, and $\mathrm{K}$ $(35 \%-60 \%)$ and smaller for $\mathrm{Ca}$ and $\mathrm{Mg}(<32 \%)$. The reduction in nutrient removals decreased in the order 


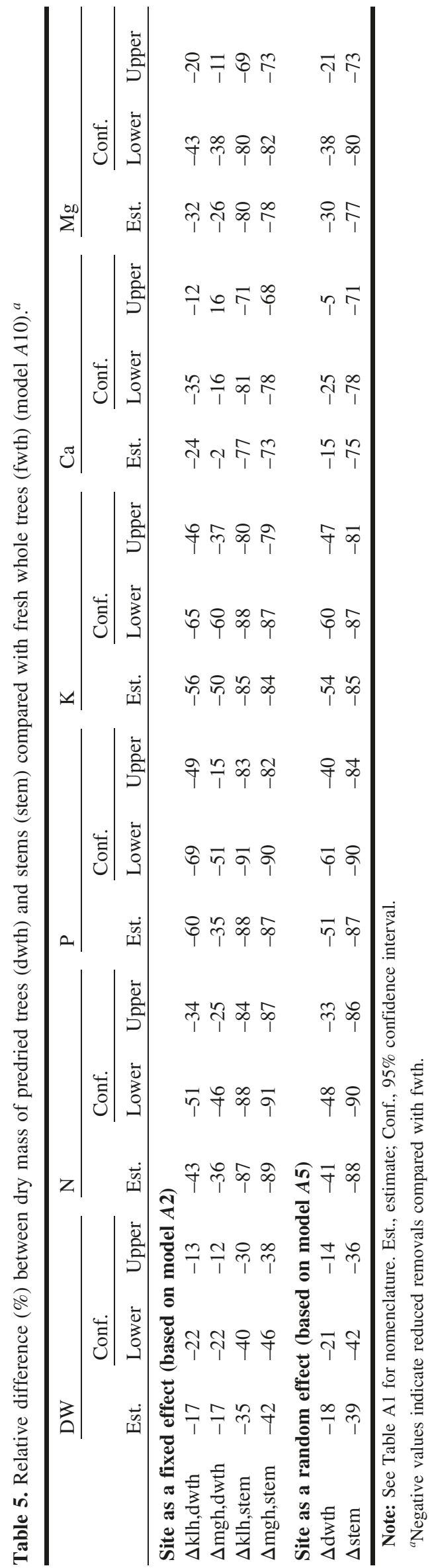

$\mathrm{P}>\mathrm{K}>\mathrm{N}>\mathrm{Mg}>\mathrm{Ca}(60 \%>56 \%>43 \%>32 \%>24 \%)$ at $\mathrm{klh}$, and $\mathrm{K}>\mathrm{N}>\mathrm{P}>\mathrm{Mg}>\mathrm{Ca}(50 \%>36 \%>35 \%>26 \%>2 \%)$ at $\mathrm{mgh}$. The relative reduction in removals was higher at klh compared with mgh, 6-7 percentage points more for N, K, and $\mathrm{Mg}$, whereas for $\mathrm{P}$ the figure was as much as 25 percentage points. Conclusions should be drawn with care for $\mathrm{Ca}$ at $\mathrm{mgh}$. The measurements suggest that there is barely any difference between the $\mathrm{Ca}$ contents of fresh and predried trees. Considering the $17 \%$ dry mass loss, $\mathrm{Ca}$ concentrations should be considerably higher for wood chips of predried trees compared with wood chips of fresh trees. However, this was not the case at klh. The observed relative differences were different at stand level (Table 2), for example, owing to differences in stocking and harvested numbers of stems.

The biomass of stems was $35 \%$ and $42 \%$ lower compared with fresh whole trees at klh and mgh, respectively. The biomass of stems thus constituted a smaller part of the total aboveground tree biomass at mgh compared with klh. The nutrient removals were considerably lower compared with harvesting of whole fresh trees, especially for $\mathrm{N}, \mathrm{P}$, and $\mathrm{K}(84 \%-$ $89 \%)$, but also to a lower extent for $\mathrm{Ca}$ and $\mathrm{Mg}(73 \%-80 \%)$ : $\mathrm{N}>\mathrm{P}>\mathrm{K}>\mathrm{Mg}>\mathrm{Ca}(88 \%>87 \%>85 \%>80 \%>77 \%)$ at $\mathrm{klh}$, and $\mathrm{P}>\mathrm{N}>\mathrm{K}>\mathrm{Mg}>\mathrm{Ca}(89 \%>87 \%>84 \%>78 \%>73 \%)$ at $\mathrm{mgh}$. For stem harvesting, site differences were less obvious for nutrients compared with biomass.

\section{Site interactions}

The equation parameters showed that the effect of height on individual tree biomass and nutrient contents was positive at both klh and mgh, but with the slope being steeper for klh compared with mgh (Table B1).

For all harvesting intensities, short trees of a certain diameter and height had a slightly greater dry mass content at mgh compared with klh, whereas the opposite was true for tall trees. The pattern was even more pronounced for nutrients, especially $\mathrm{N}, \mathrm{P}$, and $\mathrm{K}$, where short fresh trees at mgh contained up to about twice as many nutrients compared with trees of similar diameter and height at klh. The contents of $\mathrm{Ca}$ and $\mathrm{Mg}$ for short trees were up to approximately 50\% larger at mgh. For tall trees, the site differences were less pronounced, with tall fresh whole trees containing about $25 \%$ less nutrients at mgh compared with trees of similar diameter and height at klh.

Site differences to some extent interacted with harvesting intensity, even if the amount of explained variance increased $<1 \%$ when this effect was included. As such, the abovementioned site differences were less pronounced for short predried trees and stems compared with short fresh whole trees. On the other hand, differences were more pronounced for tall predried whole trees and tall stems compared with tall fresh whole trees, especially for P.

\section{Discussion}

The results of this case study indicate that the reduction in biomass removals after predrying of whole trees from thinnings in Norway spruce is rather stable from site to site, whereas the reduction in nutrient removals varies more. This is possible if the material varies with regard to composition, that is, the percentages of nutrients in needles, 
branches, bark, and stem wood, but is reduced by the same amount in net biomass removals. Site differences may be due to initial site differences in the distribution of the biomass within the tree, the level of nutrient concentrations in the various tree components, and physical and chemical losses during predrying and harvesting. These issues are discussed below, showing also the difficulties for prediction; for example, when it is based on existing biomass equations and the simple assumption that all needles are left in the stand after predrying. There are substantial uncertainties in the estimation of needle percentages; not all needles are lost, and there is probably a significant loss from other biomass components than needles. Other more technical methods have been suggested or developed to reduce nutrient removals in whole-tree harvesting. The reduction in nutrient removals when applying such methods has to some extent been quantified, and an attempt to compare with predrying is made below. Evaluating the effects of intensified biomass and nutrient removals on site fertility requires that the whole rotation is considered together with the soil nutrient pool and other site characteristics. Focussing here on the efficiency of methods to reduce nutrient removals without jeopardizing biomass yields, we refer to Raulund-Rasmussen et al. (2008) for evaluations of sustainability.

\section{Comparison with a similar study}

Our results, showing that the reduction in biomass removals after predrying of whole trees from thinnings in Norway spruce is rather stable from site to site, whereas the reduction in nutrient removals varies more, are confirmed by a similar study in a 23-year-old Norway spruce stand on fertile soil in eastern Denmark (Møller 2000). The biomass left after predrying was $16 \%$ compared with $17 \%$ in this study, with tree diameter and heights of the measured trees being within the same range. The reduction in nutrient removals was intermediate between those observed at klh and $\mathrm{mgh}$, except for $\mathrm{N}$ and $\mathrm{K}$, for which reductions were lower. As for $\mathrm{klh}$ and $\mathrm{mgh}$, the reduction in nutrient removals was larger for $\mathrm{N}, \mathrm{P}$, and $\mathrm{K}$ compared with $\mathrm{Ca}$ and $\mathrm{Mg}$. The decrease was in the order $\mathrm{P}>\mathrm{K}>\mathrm{N}>\mathrm{Mg}>\mathrm{Ca}$ $(43 \%>33 \%>29 \%>26 \%>18 \%)$.

The stems seemed to hold a smaller percentage of the tree nutrients in our study compared with the 23-year-old stand in eastern Denmark. This was especially the case for $\mathrm{K}$, but also for $\mathrm{N}, \mathrm{Ca}$, and $\mathrm{Mg}$, whereas the mean percentages of biomass and $\mathrm{P}$ were similar. The bark unintentionally being stripped off by the machinery prior to weighing of stems and sampling of stem discs in our study could have contributed to such differences. In the 23-year-old stand, the difference in nutrient contents between stems and fresh whole trees decreased in the order $\mathrm{P}>\mathrm{N}>\mathrm{Mg}>\mathrm{Ca}>\mathrm{K}$ $(88 \%>84 \%>73 \%>72 \%>71 \%)$.

\section{Biomass distribution and nutrient concentrations}

Site differences in biomass and nutrient removals may be due to differences in the initial distribution of biomass among different tree components. This distribution is affected by the overall available growing space within the stand, which is affected by, for example, age, productivity, initial stand density, and treatment history. The genetic material may also play a role. The distribution of biomass within the individual trees is also influenced by the tree's competitive status in the stand. For trees of similar diameter within a stand, shorter trees with a low competitive status must be expected to have proportionally smaller stem and crown biomass compared with taller trees with a higher competitive status. This could be called the "intrastand effect." For trees of similar diameters in two different stands, however, it has been observed that shorter trees in one stand may have proportionally larger crowns compared with taller trees in the other stand (Marklund 1988; Wirth et al. 2004). Wirth et al. (2004) attribute this negative effect of tree height to the competitive environment, so that for two trees with the same diameter, the taller tree favours height growth at the expense of crown development. This could be called the "interstand effect." The effects of crown height showed that the intrastand effect dominated in this study, but effects similar to interstand effects were also detected; short trees of similar diameters and heights contained less biomass at klh compared with mgh, whereas the opposite was true for tall trees. The explanation is probably that short trees at klh were more suppressed with smaller crowns compared with trees of similar diameters and heights in the younger and shorter stand at mgh. For dominant and more freely growing trees, this effect of competition seems to be to some extent levelled out or reversed.

Crown and needle percentages for sample trees from our study sites were estimated by the widely used biomass equations of Marklund (1988) and Wirth et al. (2004), to see if these estimates adequately predicted site differences in the relative allocation of biomass to different tree components. The estimated needle percentages were substantially greater for trees at mgh compared with klh, regardless of the equation set used. As such, greater dry matter losses should be expected at mgh compared with klh after predrying. This was, however, not the case. This discrepancy could be due to less efficient needle shedding at $\mathrm{mgh}$ and to existing equations being developed from material reflecting interstand rather than intrastand effects. However, there were large differences in estimates of biomass allocation when different equation sets were used, and interpretations should be precautious; the estimated needle percentages were substantially greater when using Marklund (1988) compared with Wirth et al. (2004), approximately $14 \%-21 \%$ versus $11 \%-12 \%$ at klh and $16 \%-$ $22 \%$ versus $14 \%-15 \%$ at mgh. Furthermore, the estimates using Marklund (1988) decreased with diameter, whereas the estimates using Wirth et al. (2004) were rather unaffected by diameter.

The biomass of stems was estimated to be $42 \%$ and $35 \%$ lower than that of fresh whole trees for mgh and klh, respectively. This should approximately correspond to crown percentages of $42 \%$ and $35 \%$, respectively. Crown percentages estimated by Marklund (1988) were slightly higher compared with estimates made by Wirth et al. (2004). However, they were higher at mgh than at klh, regardless of the equation set used. The estimated percentage of crown for individual sample trees was in the approximate range of $40 \%-$ $55 \%$ at mgh and $35 \%-50 \%$ at $\mathrm{klh}$ and decreased with tree diameter. Biomass equation estimates thus confirmed the observation that percentages of crown were greater at mgh, but it is likely that crown biomass was still overestimated 
for small trees, owing to existing equations reflecting interstand rather than intrastand effects of competition.

Stem biomass may also be influenced by competition. Both stem form and wood densities are affected by available growing space and growth rate, as expressed for example by thinning regime (Mäkinen and Isomäki 2004) and annual ring width (Olesen 1976; Wilhelmsson et al. 2002), respectively. Wirth et al. (2004) concluded that the proportion of biomass allocated to the stem was unaffected by the competitive status of the tree, but a large number of observations and a strict statistical design might be necessary to demonstrate these more subtle effects.

Observed site differences in the reduction of nutrient removals may also be influenced by different initial nutrient concentrations of the different tree components. The nutrient concentrations in biomass may vary by a factor of two (Kimmins et al. 1985). However, similar soil types and the geographical vicinity of the two sites make large differences in nutrient concentrations between the two sites unlikely. Both stands were growing on nutrient poor soils (Sundberg et al. 1999; Nord-Larsen 2002) with nutrient concentrations of current year needles in 1990 and 1993 being in the deficiency range for $\mathrm{N}$ and in the optimum range for $\mathrm{Ca}$ and $\mathrm{Mg}$ (Brække 1994; Nord-Larsen 2002). The P status was slightly better at $\mathrm{mgh}$, being at just below optimum as opposed to strong deficiency at klh. The nutritional status of $\mathrm{K}$ on the individual sites differed between the 2 measured years.

\section{Physical and chemical matter losses}

The present study did not allow for distribution of the dry matter losses to the different tree components, either physical or chemical. To the knowledge of the authors, such information is not available for whole trees from thinnings, whereas several studies exist for logging residues stored under different conditions (Mäkelä 1977; Thörnqvist 1984; Flinkman et al. 1986; Jirjis and Lehtikangas 1993; Lehtikangas and Jirjis 1993; Nurmi 1999). For example, Thörnqvist (1984) found that storage of Norway spruce logging residues in piles on the clearcut from April to October and April to April the following year caused a total dry mass loss of approximately $25 \%$ and $33 \%$, respectively. The initial shares of needles, twigs and bark, and wood were about $20 \%, 28 \%$, and $45 \%$, with $7 \%$ being dust from all components. Of the original needle, twig and bark, and wood dry mass, approximately $65 \%, 50 \%$, and $0 \%$ had been lost by October and $75 \%, 75 \%$, and $10 \%$ by April the year after. A large part, but not all of the needles, was thus lost, and there was a significant loss of biomass from other crown components.

Part of the dry matter loss in connection with predrying is due to decomposition. Nurmi (1999) found that after 1 year, the mean decomposition of needles from logging residues stored in piles on the clearcut and in a windrow was $1.8 \%$ and $0.6 \%$ per month, respectively. For Norway spruce residues stored in piles on a clearcut from February to September, a mean decomposition rate of $2 \%$ per month was found (Jirjis and Lehtikangas 1993). When the material was hauled into a windrow in May and kept there until January, the mean decomposition rate was $1 \%$ per month. If the windrow was covered with impregnated paper, the mean decomposition rate decreased to $0.2 \%$ per month. With a decomposition rate of, for example, $1 \%$ per month, the dry matter loss due to decomposition would be approximately $6 \%$ after 6 months and approximately $11 \%$ after 12 months of storage. However, dry matter losses from coarser material such as whole trees should, with all other things being equal, be lower than losses from finer logging residues.

Despite differences in quality of the material, storage conditions, and climate compared with studies made on logging residues, it is likely that a considerable part of the dry matter lost from fresh whole trees was caused by physical loss from other parts of the crowns than needles, and to some extent, also by decomposition losses. Part of the nutrients lost from predried trees could also be due to leaching from fresh needles, bark, and decomposing material. $\mathrm{K}$ is especially mobile and leached by rain (e.g., Pajuste et al. 2006). This may explain why the removal of $\mathrm{K}$ was highly reduced after predrying (Table 5). Additionally, losses occur during harvesting and chipping.

\section{Technological solutions}

Predrying of whole trees and logging residues increases the quality of the forest biomass as a fuel. The moisture content normally decreases, even if not convincingly in this study, and the mean percentage of ash is lower in wood relative to the high ash contents in needles and fine parts. But predrying also reduces the cost-effectiveness of the harvesting operation, since an additional intervention in the stand is needed (Asikainen et al. 2002) and combustion technology has developed, resulting in the moisture content of fuel now being a less important quality factor in some cases. Hakkila (2003) therefore suggests that harvesting techniques be developed to reduce the nutrient removals to acceptable amounts.

It is possible to design boom-tip mounted heads that both compact and semidefoliate trees that are harvested as whole trees (Bergström et al. 2007). This is also the case for bundling machines primarily designed for logging residues, which could also be used for other tree parts (Öhlund 2003). The above-mentioned technical solutions generally reduce the dry mass removals by 10\%-19\% (Lopéz 2000; Öhlund 2003; Bergström et al. 2007), which is similar to the level achieved by predrying. If there is a requirement for greater reduction in biomass and nutrient removals, this can be solved with technical equipment designed for that, for example, feed-rollers with sharp edges or chippers with fine particle segregation. The boom-tip mounted head mentioned above reduced the amount of harvested biomass by $11 \%-15 \%$. Ash contents in the removed material were correspondingly reduced by $35 \%-50 \%$ (Bergström et al. 2007). Compared with these technical solutions, it is evident that a larger proportion of nutrient rich material is left in the forest during predrying. This is also the case for adjusted harvesting techniques, such as leaving the tops on the site. According to Hakkila (2003), leaving a $3 \mathrm{~m}$ top in pine approximately halves the removal of needle biomass. Other methods suggested by Koistinen and Äijälä (2005) include leaving a $1-1.5 \mathrm{~m}$ top and the smallest trees or debranching of bundles when more trees are handled together.

\section{Conclusions}

We studied the biomass and nutrient removals in thin- 
nings of 39- and 48-year-old Norway spruce stands for three contemporary harvesting intensities: removal of fresh whole trees, predried whole trees, and stems only. Individual trees were removed and measured, and their level of biomass and nutrient contents were compared. Compared with removal of fresh whole trees, the biomass removals decreased 17\% after predrying, with limited variation between sites. The corresponding decrease in nutrient removals varied more between sites, and the decrease was generally larger for $\mathrm{N}, \mathrm{P}$, and $\mathrm{K}$ compared with $\mathrm{Mg}$ and $\mathrm{Ca}$. For $\mathrm{N}, \mathrm{P}$, and $\mathrm{K}$, the reduction in nutrient removals ranged between $35 \%$ and $60 \%$ and for $\mathrm{Ca}$ and $\mathrm{Mg}$ it was $<32 \%$. When only stems were removed, the biomass removals decreased by $35 \%$ and $42 \%$ for the two sites compared with fresh whole trees. The corresponding decreases in nutrient removals were $84 \%-89 \%$ for $\mathrm{N}, \mathrm{P}$, and $\mathrm{K}$ and $73 \%-80 \%$ for $\mathrm{Ca}$ and $\mathrm{Mg}$.

Across all three harvesting intensities diameter alone explained $92 \%$ of the observed variation in individual tree biomass and $>41 \%$ of the variation in nutrients contents. When harvesting intensity was included, $>98 \%$ of the variance in biomass contents and $>88 \%$ of the variance in nutrient contents could be explained. The interactions between site and tree height and site and harvesting intensity were significant but did not add much to the amount of explained variance.

A major question was the completeness of needle shedding after predrying and the possibility of estimating biomass and nutrient removals by use of existing biomass functions. To address this, estimates of percentages of needles were calculated for the sample trees based on available biomass functions from Sweden and Central Europe, respectively. The calculated estimates were very variable, depending on the set of equations used, but not clearly higher than the observed 17\% biomass loss. As shown for drying logging residues by other studies, it is likely that the biomass loss came from several tree components, such as needles, branches, twigs, and bark. It may be concluded that estimates based on existing biomass equations are uncertain, and that this uncertainty is likely to be even greater for nutrient removals. Nevertheless, the acceptable level of bias and uncertainty depends on the user's need for, for example, modelling of nutrient balances or expert evaluations of the effects of nutrient removals on site fertility and future growth.

A second question was the efficiency of predrying compared with various technical solutions that leave a part of the fresh biomass on the site. Results from the literature showed that a similar reduction in biomass removals can be obtained by technical solutions. Owing to differences in the composition of the material, however, the efficiency of technical solutions is lower when it comes to leaving nutrients onsite without decreasing biomass yields. A fundamentally different approach to mitigating potential adverse effects on site fertility is to fertilize and (or) recycle wood ash (e.g., Emilsson 2006). If compensation fertilization is accepted as a mitigation method alone, biomass yields can be maintained for the benefit of cost-efficiency in harvesting, even if this is reduced somewhat by fertilization costs.

\section{Acknowledgements}

The EU-FP5 projects "Forest Research Environment in Umeå" (FORE, HPRI-CT-2002-00198) and "Wood for energy - a contribution to the development of sustainable forest management" (WOOD-EN-MAN, QLK5-CT-200100527) funded parts of the study, together with Forest \& Landscape Denmark, University of Copenhagen. Klosterheden State Forest, Hedeselskabet (DDH), and Vestjysk Maskinstation provided indispensable help in field work. Laboratory technicians at Forest \& Landscape Denmark were helpful in the field work and laboratory analyses; we would especially like to mention Preben Frederiksen and Xhevat Haliti. Thanks also to Thomas Nord-Larsen for fruitful cooperation and data exchange and to Helle Sørensen for statistical advice.

\section{References}

Andersson, F., Brække, F., and Hallbäcken, L. 1998. Nutrition and growth of Norway spruce forests in a Nordic climatic and deposition gradient. In Imbalanced forest nutrition - vitality measures. Edited by F.O. Andersson, F.H. Brække, and F. Hallbäcken. A SNS project 1993-1996. Final report. TemaNord Forestry, 1998: 566. Nordic Council of Ministers, Copenhagen.

Asikainen, A., Björheden, R., and Nousiainen, I. 2002. Costs of wood energy. In Bioenergy from sustainable forestry - guiding principles and practice. Edited by J. Richardson, R. Björheden, P. Hakkila, A.T. Lowe, and C.T. Smith. Kluwer Academic Publishers, Dordrecht, Boston, London. pp. 125-157.

Augusto, L., Ranger, J., Ponette, Q., and Rapp, M. 2000. Relationships between forest tree species, stand production and stand nutrient amount. Ann. For. Sci. 57: 313-324. doi:10.1051/ forest:2000122.

Bergstedt, A., and Olesen, P.O. 2000. Models for predicting dry matter content of Norway spruce. Scand. J. For. Res. 15: 633644. doi:10.1080/02827580050216888.

Bergström, D., Bergsten, U., and Nordfjell, T. 2007. A New Technique for Compression of Tree Bunches from Young Stands. In Proceedings of Bioenergy 2007, 3rd International Bioenergy Conference and Exhibition, 3-6 September 2007, Jyväskylä, Finland. Edited by M. Savolainen. FINBIO publications, 36: 353-358.

Billeschou, A., and Klitgaard, O. 1985. Økologisk forsvarlig udnyttelse af marginal træressourcer - Skovstyrelsens retningslinier for statsskovene [Ecologically acceptable utilisation of marginal wood resources - the Forest Agency's recommendations for the State Forests.]. Skoven, 12: 374 375. [In Danish.]

Brække, F.H. 1994. Diagnostiske grenseverdier for næringselementer i gran- og furunåler [Diagnostic values for nutrients in spruce and pine needles]. Aktuelt fra Skogforsk 15-94: 1-11. [Tables revised by the author in 1996.] [In Norwegian.]

Emilsson, S. 2006. International handbook. From extraction of forest fuels to ash recycling. Swedish Forest Agency, Jönköping, Sweden.

European Commission. 1997. Energy for the future: renewable sources of energy. White paper for a community strategy and action plan. Com(97)599 final.

Flewelling, J.W., and Pienaar, L.V. 1981. Multiplicative regression with lognormal errors. For. Sci. 27: 281-289.

Flinkman, M., Frederikson, H., and Thörnqvist, T. 1986. Barravfall hos hyggesrester som funktion av sommarexponeringens torkeffekt [Needle waste from logging residues as a function of the drying effect of the summer exposure]. Department of Forest Products, Swedish University of Agricultural Sciences, Uppsala, Sweden, Rep. 174. [In Swedish.]

Hakkila, P. 2003. Developing technology for large-scale production of forest chips. Wood Energy Technology Programme 1999- 
2003. Interim Report. Tekes, National Technology Agency, Helsinki, Finland.

Ingerslev, M., and Hallbäcken, L. 1999. Above ground biomass and nutrient distribution in a limed and fertilized Norway spruce (Picea abies) plantation. Part II. Accumulation of biomass and nutrients. For. Ecol. Manage. 119: 21-38. doi:10. 1016/S0378-1127(98)00507-6.

Jirjis, R., and Lehtikangas, P. 1993. Bränslekvalitet och substansförluster vid vältlagring av hyggesrester [Fuel quality and dry matter loss during storage of logging residues in a windrow]. Department of Forest Products, Swedish University of Agricultural Sciences, Uppsala, Sweden. Rep. 236. [In Swedish.]

Kimmins, J.P., Binkley, D., and Hatarpaul, L. and Catanzaro, J.d. 1985. Biogeochemistry of temperate forest ecosystems: literature on inventories and dynamics of biomass and nutrients. Can. For. Serv. Inf. Rep. PI-X-47 E/F.

Koistinen, A., and Äijälä, O. 2005. Uttag av energived [Removal of energy wood]. Skogsbrukets utviklingscentral Tapio, Finland. [In Swedish.]

Lehtikangas, P., and Jirjis, R. 1993. Vältlägning av avverkningsrester från barrträd under varierende omständigheter [Windrowing of logging residues from conifers under varying conditions]. Department of Forest Products, Swedish University of Agricultural Sciences. Rep. 235. [In Swedish.]

Lopéz, P.-J. 2000. Aprovechamiento integral de biomasa en tres montes del sur de suecica. Escuela técnica superior de ingenieros agrónomos y montes. Córdoba, Espana, Escuela técnica superior de ingenieros agrónomos y montes. Departamento de ingeniería rural. Proyecto fin de carrera.

Mäkelä, M. 1977. Changes in the quality of logging residues. Folia For. (Hels.), 309. [In Finnish with summary and tables in English.]

Mäkinen, H., and Isomäki, A. 2004. Thinning intensity and longterm changes in increment and stem form of Norway spruce trees. For. Ecol. Manage. 201: 295-309. doi:10.1016/j.foreco. 2004.07.017.

Marklund, L.G. 1988. Biomassafunktioner för tall, gran och björk i Sverige [Biomass functions for Scots pine, Norway spruce and birch in Sweden]. Institutionen for Skogstaxering, Swedish University of Agricultural Sciences. Rep. 45. [In Swedish with English translations of variables.]

Møller, I.S. 2000. Calculation of biomass and nutrient removal for different harvesting intensities. N.Z. J. For. Sci. 30: 29-45.

Nord-Larsen, T. 2001. Flishugst i tynding og træernes vækst [Wood chipping in thinnings and tree growth]. Forskningscentret for Skov \& Landskab, Hørsholm, Denmark, Anlægsrapport 599. [In Danish.]

Nord-Larsen, T. 2002. Stand and site productivity response following whole-tree harvesting in early thinnings of Norway spruce (Picea abies (L.) Karst.). Biomass Bioenergy, 23: 1-12. doi:10. 1016/S0961-9534(02)00032-6.

Nord-Larsen,T., and Heding, N. 2003. Træbrændselsressourcer fra de danske skove, prognose 2002 [Wood fuel resources from the Danish Forests, prognosis 2002]. Dansk Skovbrugs Tidsskrift 1/ 03. [In Danish.]

Nurmi, J. 1999. The storage of logging residue for fuel. Biomass Bioenergy, 17: 41-47. doi:10.1016/S0961-9534(99)00023-9.

Olesen, P.O. 1976. The interrelation between basic density and ring width of Norway spruce. Forstl. Forsogsvæs. Dan. XXXIV: 339-360.

Öhlund, A. 2003. Productivity study in bundling logging residues and small stems with WoodPac. Forest Technology, Swedish University of Agricultural Sciences, Umeå, Sweden. Student rep. 60.
Pajuste, K., Frey, J., and Asi, E. 2006. Interactions of atmospheric deposition with coniferous canopies in Estonia. Environ. Monit. Assess. 112: 177-196. doi:10.1007/s10661-006-0360-x. PMID: 16404540 .

Raulund-Rasmussen, K., Stupak, I., Clarke, N., Callesen, I., Helmisaari, H.-S., Karltun, E., and Varnagiryte-Kasbaskiene, I. 2008. Effects of very intensive forest biomass harvesting on short and long-term site productivity. In Sustainable use of forest biomass for energy - a synthesis with focus on the Nordic and Baltic Region. Edited by D. Röser, A. Asikainen, K. Raulund-Rasmussen, and I. Stupak. Managing Forest Ecosystems, 12: 29-78.

SAS Institute Inc. 2002-2003. SAS Version 9.1. SAS Institute Inc. Cary, N.C.

Simola, P., and Mäkelä, M. 1976. Leaf-seasoning method in wholetree logging. Folia For. (Hels.), 273: . [In Finnish with summary and tables in English.]

Skovsgaard, J.P., Stupak, I., and Vesterdal, L. 2006. Distribution of biomass and carbon in even-aged stands of Norway spruce (Picea abies (L.) Karst.): a case study on spacing and thinning effects in northern Denmark. Scand. J. For. Res. 21: 470-488. doi: $10.1080 / 02827580601056268$.

Statistics Denmark. 2007. Felling in forest and plantation in Denmark. Available from www.statistikbanken.dk/ [accessed 6 November 2007].

Sundberg, P.S., Callesen, I., Greve, M.H., and Raulund-Rasmussen, K. 1999. Danske jordbundsprofiler [Danish soil profiles]. Danmarks Jordbrugsforskning, Foulum, Denmark. [In Danish.]

Thörnqvist, T. 1984. Hyggeresternes förändring på hygget under två vegatationsperioder [The change of logging residues on the clear cut over two vegetation periods]. Department of Forest Products, Swedish University of Agricultural Sciences. Rep. 150. [In Swedish.]

West-Nielsen, G. 1950. Rødgranens produktionsforhold på den midtjydske hede [The production of Norway spruce on the MidJutland heath lands]. Hedenselskabets Tidsskift 71. [In Danish.]

Wilhelmsson, L., Arlinger, J., Spångberg, K., Lundqvist, S.-O., Grahn, T., Hedenberg, Ö., and Olsson, L. 2002. Models for predicting wood properties in stems of Picea abies and Pinus sylvestris in Sweden. Scand. J. For. Res. 17: 330-350. doi:10. 1080/02827580260138080.

Wirth, C., Schumacher, J., and Schulze, E.D. 2004. Generic biomass functions for Norway spruce in Central Europe - a metaanalysis approach toward prediction and uncertainty estimation. Tree Physiol. 24: 121-139. PMID:14676030.

Zianis, D., Muukkonen, P., Mäkipää, R., and Mencuccini, M. 2005. Biomass and stem volume equations for tree species in Europe. Silva Fenn. Monogr. 4.

\section{Appendix A}

This appendix specifies the models and analyses on which the results of this paper are based. The analyses were performed using the SAS version 9.1 (SAS Institute Inc. 20022003). The method presented below allows for comparison of harvesting intensities without disturbance from interactions with stand level characteristics, such as stocking and harvesting regime. As far as possible, disturbances from interactions with tree size are also eliminated. The capital letters A-E correspond to those listed in the Materials and methods section and an overview of nomenclature is given in Table A1. 
Table A1. Research nomenclature.

\begin{tabular}{|c|c|c|}
\hline \multicolumn{3}{|c|}{ Variable } \\
\hline $\bar{Y}$ & $=$ & Individual tree biomass or content of the nutrient $Z\left(\mathrm{~kg} \cdot \operatorname{tree}^{-1}\right.$ or g.tree $\left.{ }^{-1}\right)$ \\
\hline$c$ & $=$ & Nutrient concentrations of individual wood chip or stem disc sample $\left(\mathrm{mg} \cdot \mathrm{g}^{-1}\right)$ \\
\hline$d$ & $=$ & Diameter at breast height of the individual tree at $1.3 \mathrm{~m}(\mathrm{~cm})$ \\
\hline$h$ & $=$ & Tree height from the ground $(\mathrm{m})$ \\
\hline $\mathrm{ch}$ & $=$ & Height from the ground to the crown base $(\mathrm{m})$ \\
\hline$n$ & $=$ & Number of observations \\
\hline \multicolumn{3}{|c|}{ Parameters } \\
\hline$\beta$ & $=$ & Fixed effect \\
\hline$R$ & $=$ & Random effect \\
\hline MS & $=$ & Squared SD of a random effect \\
\hline \multicolumn{3}{|c|}{ Calculated estimates } \\
\hline$\Delta_{\mathrm{HI}, S}$ & $=$ & $\begin{array}{l}\text { Relative difference in individual tree nutrient content for } \mathrm{HI}=\text { dwth or stem rela- } \\
\text { tive to fwth at } S=\text { klh or mgh (no unit) }\end{array}$ \\
\hline$\delta_{\mathrm{HI}}$ & $=$ & $\begin{array}{l}\text { Individual tree biomass or nutrient content for mgh relative to klh for treatment } \\
\mathrm{HI}=\text { fwth, dwth, or stem (no unit) }\end{array}$ \\
\hline $\mathrm{CF}$ & $=$ & Factor for correction of logarithmic bias \\
\hline \multicolumn{3}{|c|}{ Terms used with variables, parameters, estimates } \\
\hline$Z$ & $=$ & Nutrient, $Z=$ dry mass (DW), N, P, K, Ca, or $\mathrm{Mg}$ \\
\hline HI & $=$ & Harvesting intensity, $\mathrm{HI}=$ fwth, dwth, or stem \\
\hline$S$ & $=$ & Site, $S=$ klh or mgh \\
\hline$B$ & $=$ & Block, $B=1-6$ \\
\hline PL & $=$ & Plot, PL $=1-24$ \\
\hline
\end{tabular}

Note: klh, Klosterheden National Forest; mgh, Mangehøje Forest; fwth, fresh whole-tree harvesting; dwth, dry whole-tree harvesting; stem, harvesting of stems only.

\section{A.}

The full model when testing site as a systematic effect was

$$
\begin{aligned}
& \ln Y_{Z}=\beta_{0}+\beta_{\mathrm{HI}}+\beta_{S}+\beta_{\mathrm{HI} \times S}+\beta_{1} \ln d+\beta_{2} \ln h \\
& +\beta_{3 S} \ln d+\beta_{4 S} \ln h+\beta_{5 \mathrm{HI}} \ln d \\
& \quad+\beta_{6 \mathrm{HI}} \ln h+R_{B(S)}+R_{\mathrm{PL}(B)}+\varepsilon
\end{aligned}
$$

For DW and all nutrients, all fixed main effects and the interactions between site and height were significant. The interactions between site and harvesting intensity were only significant for $Z=\mathrm{DW}, \mathrm{P}$, and almost for $\mathrm{Ca}$, but the effect was included in the final models for all nutrients. Even if block and plot effects were not significant (WALD-Z test, option COVTEST), they were also included into the final model:

$$
\begin{array}{r}
\ln Y_{Z}=\beta_{0}+\beta_{\mathrm{HI}}+\beta_{S}+\beta_{\mathrm{HI} \times S}+\beta_{1} \ln d+\beta_{2} \ln h \\
+\beta_{3 S} \ln h+R_{B(S)}+R_{\mathrm{PL}(B)}+\varepsilon
\end{array}
$$

The additional effect of crown height was analysed for the data for fresh whole tree harvesting (fwth) separately. The block and plot effects were identical in this case, and therefore only block was included. The interaction between site and crown height was not significant for any values of $Z$ and the final model was

$$
\begin{aligned}
\text { [A3] } \quad \ln Y_{Z}=\beta_{0}+\beta_{S}+\beta_{1} \ln d & +\beta_{2} \ln h+\beta_{3} \ln \mathrm{ch} \\
& +\beta_{4 S} \ln h+R_{B(S)}+\ln \varepsilon
\end{aligned}
$$

\section{B.}

The full model when testing site as a random effect was

$$
\begin{aligned}
\ln Y_{Z}=\beta_{0}+\beta_{\mathrm{HI}} & +\beta_{1} \ln d+\beta_{2} \ln h+\beta_{3 \mathrm{HI}} \ln d \\
& +\beta_{4 \mathrm{HI}} \ln h+B_{S}+R_{B(S)}+R_{\mathrm{PL}(B)}+\varepsilon
\end{aligned}
$$

The main fixed effects were significant. The interactions between harvesting intensity and diameter and height were not significant. The interactions between harvesting intensity and diameter were close to significant for $\mathrm{P}(p=0.061)$ and $\mathrm{K}(p=0.053)$, but still left out. None of the random effects were significant (WALD- $Z$ test), but they were, however, included in the final model:

$$
\begin{aligned}
\ln Y_{Z}=\beta_{0}+\beta_{\mathrm{HI}}+\beta_{1} \ln d+\beta_{2} \ln h+ & B_{S}+R_{B(S)} \\
& +R_{\mathrm{PL}(B)}+\varepsilon
\end{aligned}
$$

Parameters were estimated in PROC MIXED, and after correction for logarithmic bias, the prediction function was

$$
\begin{aligned}
Y_{Z}=\exp \left[\beta_{0}\right. & +\beta_{\mathrm{HI}}+\beta_{1} \ln d+\beta_{2} \ln h \\
& \left.+\left(\mathrm{MS}_{S}+\mathrm{MS}_{B(S)}+\mathrm{MS}_{\mathrm{PL}(B)}+\mathrm{MS}_{e}\right) / 2\right]
\end{aligned}
$$

C.

To explore the importance of the different explaining factors $R^{2}$ was obtained from a number of successive models analysed in PROC GLM, adding one effect at a time, starting with

[A7] $\quad \ln Y_{Z}=\beta_{0}+\beta_{1} \ln d+\ln \varepsilon$ 
and ending with

$$
\begin{aligned}
\ln Y_{Z}=\beta_{0}+\beta_{\mathrm{HI}}+\beta_{S}+\beta_{\mathrm{HI} \times S}+\beta_{1} \ln d & +\beta_{2} \ln h \\
& +\beta_{3 S} \ln h+\varepsilon
\end{aligned}
$$

The factors were included according to the decreasing size of the sum of squares (SS) from a type III test, $Z=\mathrm{DW}$.

Data for fwth were analysed alone in the same manner including only crown height. The first model in the successive test was $A 7$ and the last model was

$$
\begin{aligned}
\ln Y_{Z}=\beta_{0}+\beta_{S}+\beta_{1} \ln d+\beta_{2} \ln h & +\beta_{3} \ln \mathrm{ch} \\
& +\beta_{4 S} \ln h+\ln \varepsilon
\end{aligned}
$$

\section{D.}

Based on model $A 2$, the relative differences in dry mass contents among harvesting intensities could be estimated. As there was no interaction between harvesting intensity and numerical predictors, the estimates were constants that were independent of tree size for each site and harvesting intensity:

$$
\Delta_{\mathrm{HI}, S, Z}=\left[\exp \left(\beta_{\mathrm{HI}}-\beta_{\mathrm{fwth}}+\beta_{\mathrm{HI}, S}-\beta_{\mathrm{fwth}, S}\right)-1\right]
$$$$
\times 100
$$

where HI is dry whole-tree harvesting (dwth) or stem harvesting (stem) and $S$ is Klosterheden National Forest (klh) or Mangehøje Forest (mgh). The constant expresses the relative difference $(\%)$ in biomass or nutrient removals when trees are predried or when only stems are removed, compared with removal of the whole fresh trees. These relative differences were similarly calculated based on model A5. Values and confidence intervals of the combined parameters were estimated in PROC MIXED using ESTIMATE including option CL and transformed back to arithmetic scales.

The site differences in biomass levels could be estimated similarly based on model $A 2$. As there was a significant interaction between site and height, the site differences were height dependent:

$$
\begin{aligned}
\delta_{\mathrm{HI}, Z}=\exp \left[\beta_{\mathrm{mgh}}-\beta_{\mathrm{klh}}+\beta_{\mathrm{mgh}, \mathrm{HI}}-\beta_{\mathrm{klh}, \mathrm{HI}}\right. & \\
& \left.+\left(\beta_{3 \mathrm{mgh}}-\beta_{3 \mathrm{klh}}\right) \ln h\right]
\end{aligned}
$$

where HI is fwth, dwth, or stem. The constant expresses the biomass or nutrient content of a tree at mgh relative to that of a tree at klh of similar diameter and height. Values of the combined parameters, intercept and slope, were estimated in PROC MIXED using ESTIMATE.

\section{E.}

Allometric relationships were modelled for predictor variables of sample trees. For height, the full model was

$$
\begin{aligned}
h=\beta_{0}+\beta_{S}+\beta_{1} \ln d+\beta_{2 S} \ln d+R_{B(S)} & \\
& +R_{\mathrm{PL}(B)}+\varepsilon
\end{aligned}
$$

The effect of site alone was not significant $(p=0.16)$, whereas the interaction between site and diameter was. Random effects were not significant either. Nevertheless, all effects of the full model were finally included.

The full model for the crown height was

$$
\begin{aligned}
\mathrm{ch}=\beta_{0}+\beta_{S}+\beta_{1} \ln d+\beta_{2} \ln h & +\beta_{3 S} \ln d \\
& +\beta_{4 S} \ln h+R_{B(S)}+\varepsilon
\end{aligned}
$$

The effect of site and its interactions with diameter and height were not significant. The main effect of site was however left in the model. The effect of block was not significant either, but also left in the model:

$$
\mathrm{ch}=\beta_{0}+\beta_{S}+\beta_{1} \ln d+\beta_{2} \ln h+R_{B(S)}+\varepsilon
$$

\section{References}

SAS Institute Inc. 2002-2003. SAS version 9.1. SAS Institute Inc. Cary, N.C.

\section{Appendix B}

Appendix B appears on the following page. 
Table B1. Parameters of individual tree dry matter equations (model $A 2)$ : $\ln Y_{Z}=\beta_{0}+\beta_{H I}+\beta_{S}+\beta_{\mathrm{HI} \times S}+\beta_{1} \ln d+\beta_{2} \ln h+\beta_{3 S} \ln h+R_{B(S)}+R_{\mathrm{PL}(B)}+\varepsilon$.

\begin{tabular}{|c|c|c|c|c|c|c|c|c|c|c|c|c|c|c|}
\hline & \multirow[b]{2}{*}{$\mathrm{HI}$} & \multirow[b]{2}{*}{$\mathrm{S}$} & \multicolumn{2}{|l|}{ DW } & \multicolumn{2}{|l|}{$\mathrm{N}$} & \multicolumn{2}{|l|}{$\underline{P}$} & \multicolumn{2}{|l|}{$\mathrm{K}$} & \multicolumn{2}{|l|}{$\mathrm{Ca}$} & \multicolumn{2}{|l|}{$\mathrm{Mg}$} \\
\hline & & & Parm. & SD & Parm. & SD & Parm. & SD & Parm. & SD & Parm. & SD & Parm. & SD \\
\hline$\overline{\beta_{0}}$ & & & -2.8759 & 0.1530 & -2.8063 & 0.3524 & -5.2324 & 0.5465 & -3.6635 & 0.4132 & -2.1086 & 0.3699 & -3.8869 & 0.3111 \\
\hline \multirow{3}{*}{$\beta_{\mathrm{HI}}$} & fwth & & 0.5475 & 0.0354 & 2.2024 & 0.0886 & 2.0154 & 0.1472 & 1.8228 & 0.1204 & 1.3269 & 0.0908 & 1.5123 & 0.0972 \\
\hline & dwth & & 0.3611 & 0.0364 & 1.7516 & 0.0928 & 1.5814 & 0.1536 & 1.1373 & 0.1249 & 1.3100 & 0.0956 & 1.2149 & 0.0937 \\
\hline & stem & & 0 & - & 0 & - & 0 & - & 0 & - & 0 & - & 0 & - \\
\hline \multirow[t]{2}{*}{$\beta_{\mathrm{S}}$} & & klh & -0.4954 & 0.2033 & -1.8452 & 0.4691 & -2.8285 & 0.7297 & -2.3235 & 0.5516 & -1.4127 & 0.4942 & -1.4303 & 0.4168 \\
\hline & & $\mathrm{mgh}$ & 0 & - & 0 & 0 & 0 & - & 0 & - & 0 & 0 & 0 & - \\
\hline \multirow[t]{6}{*}{$\beta_{\mathrm{H}(S)}$} & fwth & klh & -0.1123 & 0.0511 & -0.1534 & 0.1315 & 0.0843 & 0.2194 & -0.0475 & 0.1791 & 0.1228 & 0.1354 & -0.1178 & 0.1401 \\
\hline & dwth & klh & -0.1151 & 0.0523 & -0.2644 & 0.1343 & -0.3989 & 0.2235 & -0.0992 & 0.1820 & -0.1350 & 0.1384 & -0.2079 & 0.1423 \\
\hline & stem & klh & 0 & - & 0 & - & 0 & - & 0 & - & 0 & - & 0 & - \\
\hline & fwth & $\mathrm{mgh}$ & 0 & - & 0 & - & 0 & - & 0 & - & 0 & - & 0 & - \\
\hline & dwth & $\mathrm{mgh}$ & 0 & - & 0 & - & 0 & - & 0 & - & 0 & - & 0 & - \\
\hline & stem & $\mathrm{mgh}$ & 0 & - & 0 & - & 0 & - & 0 & - & 0 & - & 0 & - \\
\hline$\beta_{1}$ & & & 1.8982 & 0.0669 & 1.9129 & 0.1560 & 1.8797 & 0.2432 & 2.2235 & 0.1843 & 1.7493 & 0.1642 & 1.9667 & 0.1388 \\
\hline$\beta_{2}$ & & & 0.5802 & 0.1157 & 0.3120 & 0.2689 & 0.3045 & 0.4185 & 0.0860 & 0.3168 & 0.3071 & 0.2825 & 0.2445 & 0.2381 \\
\hline \multirow[t]{2}{*}{$\beta_{3 S}$} & & klh & 0.2474 & 0.0871 & 0.8269 & 0.1999 & 1.3621 & 0.3085 & 1.0244 & 0.2327 & 0.7135 & 0.2093 & 0.6113 & 0.1741 \\
\hline & & $\mathrm{mgh}$ & 0 & - & 0 & 0 & 0 & - & 0 & - & 0 & - & 0 & - \\
\hline $\mathrm{MS}_{B(S)}$ & & & 0.0002 & 0.0005 & 0.0018 & 0.0044 & 0.0101 & 0.0152 & 0.0028 & 0.0077 & 0.0075 & 0.0073 & 0.0059 & 0.0071 \\
\hline $\mathrm{MS}_{\mathrm{PL}(B)}$ & & & 0 & - & 0.0032 & 0.0057 & 0.0137 & 0.0150 & 0.0121 & 0.0104 & 0.0029 & 0.0058 & 0.0081 & 0.0064 \\
\hline $\mathrm{MS}_{e}$ & & & 0.0072 & 0.0012 & 0.0371 & 0.0065 & 0.0876 & 0.0152 & 0.0500 & 0.0087 & 0.0404 & 0.0072 & 0.0277 & 0.0048 \\
\hline
\end{tabular}

Note: See Table A1 for nomenclature. Parm, parameter estimate; klh, Klosterheden National Forest; mgh, Mangehøje Forest; fwth, fresh whole-tree harvesting; dwth, dry whole-tree harvesting. Units: $Y$, $\mathrm{kg} \cdot$ tree $^{-1}$ (DW) or g.tree ${ }^{-1}$ (nutrients); $d$, centimetres; $h$, metres.

Table B2. Parameters of individual tree dry matter equations (model A5): $\ln Y_{Z}=\beta_{0}+\beta_{\mathrm{HI}}+\beta_{1} \ln d+\beta_{2} \ln h+B_{S}+R_{B(S)}+R_{\mathrm{PL}(B)}+\varepsilon$.

\begin{tabular}{|c|c|c|c|c|c|c|c|c|c|c|c|c|c|}
\hline & \multirow[b]{2}{*}{$\mathrm{HI}$} & \multicolumn{2}{|l|}{ DW } & \multicolumn{2}{|l|}{$\mathrm{N}$} & \multicolumn{2}{|l|}{$\mathrm{P}$} & \multicolumn{2}{|l|}{ K } & \multicolumn{2}{|l|}{$\mathrm{Ca}$} & \multicolumn{2}{|l|}{$\mathrm{Mg}$} \\
\hline & & Parm. & SD & Parm. & SD & Parm. & $\mathrm{SD}$ & Parm. & SD & Parm. & SD & Parm. & SD \\
\hline$\overline{\beta_{0}}$ & & -3.1454 & 0.1119 & -3.8462 & 0.2832 & -7.0430 & 0.4170 & -4.8782 & 0.3094 & -2.9791 & 0.2946 & -4.6706 & 0.2540 \\
\hline \multirow[t]{3}{*}{$\beta_{\mathrm{HI}}$} & fwth & 0.4967 & 0.0272 & 2.1382 & 0.0723 & 2.0820 & 0.1252 & 1.8528 & 0.0834 & 1.3907 & 0.0729 & 1.4625 & 0.0718 \\
\hline & dwth & 0.3035 & 0.0279 & 1.6113 & 0.0737 & 1.3624 & 0.1276 & 1.0753 & 0.0852 & 1.2218 & 0.0744 & 1.1057 & 0.0730 \\
\hline & stem & 0 & - & 0 & - & 0 & - & 0 & - & 0 & - & 0 & - \\
\hline$\beta_{1}$ & & 1.8904 & 0.0684 & 1.8641 & 0.1683 & 1.6803 & 0.2599 & 2.2333 & 0.1926 & 1.6617 & 0.1724 & 1.9438 & 0.1470 \\
\hline$\beta_{2}$ & & 0.7243 & 0.1021 & 0.8412 & 0.2551 & 1.3969 & 0.3873 & 0.6281 & 0.2855 & 0.8462 & 0.2626 & 0.6132 & 0.2248 \\
\hline $\mathrm{MS}_{S}$ & & 0.0003 & 0.0008 & 0.0101 & 0.0171 & 0.0001 & 0.0087 & 0 & - & 0.0145 & 0.0251 & 0.0134 & 0.0232 \\
\hline $\mathrm{MS}_{B(S)}$ & & 0.0003 & 0.0006 & 0.0013 & 0.0048 & 0.0027 & 0.0148 & 0.0030 & 0.0063 & 0.0062 & 0.0071 & 0.0054 & 0.0070 \\
\hline $\operatorname{MS}_{\mathrm{PL}(B)}$ & & 0 & - & 0.0039 & 0.0064 & 0.0200 & 0.0187 & 0.0040 & 0.0078 & 0.0036 & 0.0058 & 0.0077 & 0.0064 \\
\hline $\mathrm{MS}_{e}$ & & 0.0082 & 0.0013 & 0.0454 & 0.0078 & 0.1116 & 0.0190 & 0.0640 & 0.0110 & 0.0466 & 0.0080 & 0.0323 & 0.0056 \\
\hline $\mathrm{CF}$ & & 0.0044 & & 0.0303 & & 0.0672 & & 0.0355 & & 0.0354 & & 0.0294 & \\
\hline
\end{tabular}

Note: See Table A1 for nomenclature. Parm, parameter estimate. Units: $Y, \mathrm{~kg} \cdot$ tree $^{-1}(\mathrm{DW})$ or $\mathrm{g} \cdot$ tree $^{-1}$ (nutrients); $d$, centimetres; $h$, metres. 